\title{
SYMPOSIUM FOREWORD
}

Symposium on 'Indigenous Water Rights in Comparative Law', held at the University of Canterbury School of Law, Christchurch (New Zealand), on 7 Dec. 2018, funded by the New Zealand Law Foundation

\section{Indigenous Water Rights in Comparative Law}

\author{
Elizabeth Macpherson*
}

At the end of the 2015 Academy Award-winning film The Big Short, which explores the origins of the 2008 Global Financial Crisis, a caption notes that the Wall Street investor protagonist of the film who predicted the collapse of the United States (US) housing market would now be 'focused on one commodity: water'. ${ }^{1}$ Water is sometimes described in popular culture as 'the new oil'? or 'more valuable than gold' ${ }^{3}$ It is predicted to be the subject of increasing uncertainty, competition, conflict, and even war, ${ }^{4}$ as increasing demand from a growing human population and development meets reduced supply as a result of poor management, overuse, and climate change. ${ }^{5}$

In this uncertain and increasingly competitive aquatic future, Indigenous peoples continue to contest for water governance, ownership and sovereignty across the globe. As described by Indigenous scholars and pursuant to traditional laws and customs, Indigenous peoples are intrinsically connected to their water taonga ('treasures' in the Māori language), and have wide-ranging practical, spiritual, environmental, cultural, and economic interests in, relationships with, obligations towards, and

* University of Canterbury School of Law, Christchurch (New Zealand).

Email: elizabeth.macpherson@canterbury.ac.nz.

I would like to thank the New Zealand Law Foundation for their generous support of the project on 'Indigenous Water Rights in Comparative Law' (2018/45/2) and the 2018 research workshop. I would also like to thank the funded keynote speakers at the workshop: Lee Godden (University of Melbourne, Australia), Jacinta Ruru (University of Otago, New Zealand), and Maria de Pilar Garcia Pachón (University Externado de Colombia, Colombia).

1 The Big Short (Paramount Pictures UK, 2015), closing captions, referring to Michael Burry.

2 J. Brookes, 'Why Water Is the New Oil', Rolling Stone, 7 July 2011, available at: https://www.rollingstone.com/politics/politics-news/why-water-is-the-new-oil-198747.

3 P.M. Sheridan, 'Water Becoming More Valuable than Gold', CNNMoney, 24 Apr. 2014, available at: https://money.cnn.com/2014/04/24/news/water-gold-price/index.html.

4 B. Chellaney, Water, Peace, and War: Confronting the Global Water Crisis, updated edn (Rowman \& Littlefield, 2013); M. De Villiers, Water Wars: Is the World's Water Running Out? (Weidenfeld \& Nicolson, 1999).

5 See R. Larson, Just Add Water: Solving the World's Problems Using Its Most Precious Resource (Oxford University Press, 2020), pp. 1-10. For a discussion of human-driven impacts on the environment generally, see S. Díaz et al., 'Pervasive Human-driven Decline of Life on Earth Points to the Need for Transformative Change' (2019) 366(6471) Science, pp. 1-10. 
dependencies on water resources. ${ }^{6}$ As an example, the Fitzroy River Declaration recognizes that the Martuwarra River in north-western Australia 'is a living ancestral being and has a right to life. It must be protected for current and future generations, and managed jointly by the Traditional Owners of the river'. ${ }^{7}$ The legal nature of Indigenous water rights as recognized in western law is also complex, ${ }^{8}$ with rights and entitlements typically fragmented across a complicated 'patchwork' of tenures.'

Indigenous water rights are increasingly acknowledged in comparative and international legal documents, including recently in Principle 3 of the 2018 Brasília Declaration of Judges on Water Justice, which provides that '[I]ndigenous and tribal peoples' rights to and relationships with traditional and/or customary water resources and related ecosystems should be respected, and their free, prior, and informed consent should be required for any activities on or affecting water resources and related ecosystems' ${ }^{10}$ However, despite a comparative tendency towards the 'greening of water laws' around the world, ${ }^{11}$ western laws typically still fail to recognize and provide for the full extent of Indigenous rights to water, denying Indigenous peoples both procedural rights in water planning and management frameworks, and substantive water use rights and allocations. ${ }^{12}$ This continuing failure of law and policy is a source of ongoing trauma

6 See, e.g., L.B. Taylor et al., 'Ngā Puna Aroha: Towards an Indigenous-centred Freshwater Allocation Framework for Aotearoa New Zealand' (2020) Australasian Journal of Water Resources online articles, pp. 1-13, at 2, available at: https://www.tandfonline.com/doi/abs/10.1080/13241583.2020.1792632? af=R\&journalCode=twar20; J. Ruru, 'Listening to Papatūānuku: A Call to Reform Water Law' (2018) 48(2-3) Journal of the Royal Society of New Zealand, pp. 215-24; V. Marshall, Overturning Aqua Nullius: Securing Aboriginal Water Rights (Aboriginal Studies Press, 2017); A.Á. Marín, 'Constitutional Challenges of the South: Indigenous Water Rights in Chile Another Step in the “Civilizing Mission”?' (2017) 33(3) Windsor Yearbook of Access to Justice, pp. 87-110; L. Te Aho, 'Te Mana o Te Wai: An Indigenous Perspective on Rivers and River Management' (2019) 35(10) River Research and Applications, pp. 1615-21; A. Poelina, K.S. Taylor \& I. Perdrisat, 'Martuwarra Fitzroy River Council: An Indigenous Cultural Approach to Collaborative Water Governance' (2019) 26(3) Australasian Journal of Environmental Management, pp. 236-54. See also S. Babidge, 'Contested Value and an Ethics of Resources: Water, Mining and Indigenous People in the Atacama Desert, Chile' (2016) 27(1) The Australian Journal of Anthropology, pp. 84-103, at 85 (Babidge frames these wide-ranging interests in the Chilean context as being part of 'complex waterscapes').

7 Fitzroy River Council, 'Fitzroy River Declaration', 3 Nov. 2016, available at: https://static1.squarespace. com/static/5e86add4e98f7421bace70f1/t/5e9fcc157dedb86cbb06a2e9/1587530798453/fitzroy-riverdeclaration.pdf.

8 This complexity is compounded by the general complexity of trans-jurisdictional water law and governance; in this regard, see J. Gray, C. Holley \& R.G. Rayfuse, Trans-jurisdictional Water Law and Governance (Routledge, 2016).

9 For a discussion of the problem of a 'patchwork' of Indigenous water rights in the US context, see P. Womble et al., 'Indigenous Communities, Groundwater Opportunities' (2018) 361(6401) Science, pp. 453-5, at 453 .

10 Brasília Declaration of Judges on Water Justice (10 Principle Declaration), $8^{\text {th }}$ World Water Forum, Brasília (Brazil), 21 Mar. 2018, Principle 3, available at: https://www.iucn.org/sites/dev/files/content/ documents/brasilia_declaration_of_judges_on_water_justice_21_march_2018_final_as_approved_0. pdf.

11 See S. Burchi, 'The Future of Domestic Water Law: Trends and Developments Revisited, and Where Reform is Headed' (2019) 44(3) Water International, pp. 1-20.

12 See, e.g., L.D. Hartwig, S. Jackson \& N. Osborne, 'Trends in Aboriginal Water Ownership in New South Wales, Australia: The Continuities between Colonial and Neoliberal Forms of Dispossession' (2020) 99 Land Use Policy, pp. 1-13; K.S. Taylor, B.J. Moggridge \& A. Poelina, 'Australian Indigenous Water Policy and the Impacts of the Ever-changing Political Cycle' (2016) 20(2) Australasian Journal of Water Resources, pp. 132-47; Taylor et al., n. 6 above. 
for Indigenous peoples, ${ }^{13}$ who seek reparative and distributive justice for their political claims to water rights and regulation, ${ }^{14}$ as water health continues to deteriorate and other users continue to benefit from the development of Indigenous water treasures. ${ }^{15}$

This Symposium collection is the result of a Research Workshop on Indigenous Water Rights in Comparative Law, held at the University of Canterbury School of Law Christchurch (New Zealand), in December 2018, and generously funded by the New Zealand Law Foundation. This workshop brought together over 50 comparative researchers on Indigenous water rights from around the world, including Indigenous researchers and experts. The workshop enabled discussion and debate on Indigenous water rights from multiple perspectives, and provided an intellectual foundation for the themes visited in this collection.

Because of the inherently transdisciplinary nature of water research, the collection is interdisciplinary in approach, and the authors represent a range of academic disciplines from law and the broader social and physical sciences, with close attention paid to the 'context to the law'. ${ }^{16}$ It has been a decidedly collaborative effort, with most articles being co-developed and co-authored, and with strong representation from early-career and female researchers. The interdisciplinary focus of the collection emphasizes Indigenous ontologies, sources and research methods. Half of the articles have Indigenous authorship, and others have Indigenous heritage or whakapapa [genealogical and familial connections] and champion Indigenous-led enquiry. It is nevertheless important to acknowledge that the rights of Indigenous peoples are at times discussed or presented in this collection by people who are not Indigenous, and I wish to emphasize that we do not speak collectively for Indigenous aspirations or experience, and we rely on and defer to the rich body of Indigenous scholarship and leadership in this field.

It continues to surprise that Latin America remains under-represented in comparative research about water, despite significant water issues being faced in the region, which is also a leading source of jurisprudence on these issues. ${ }^{17}$ This is the case especially in Australasian scholarship, which is the home base of many of our contributors. ${ }^{18}$ This collection has a distinctive Australasia/Latin America comparative focus,

13 J. Reid et al., The Colonising Environment: An Aetiology of the Trauma of Settler Colonisation and Land Alienation on Ngāi Tahu Whānau (UC Ngāi Tahu Research Centre, 2017).

14 Here I rely on B. Morgan, The Intersection of Rights and Regulation: New Directions in Sociolegal Scholarship (Ashgate, 2007), who has emphasized the need for socio-legal scholarship to pay attention to issues of both rights and regulation.

15 E. Macpherson, Indigenous Rights to Water in Law and Regulation: Lessons from Comparative Experience (Cambridge University Press, 2019), pp. 215-21. See also M.M. Douglas et al., 'Conceptualizing Hydro-socio-ecological Relationships to Enable More Integrated and Inclusive Water Allocation Planning' (2019) 1(3) One Earth, pp. 361-73, at 363. Douglas and others have recently developed a 'hydro-socio-ecological conceptual model' to describe the impacts of water abstraction on Indigenous peoples' water rights in Australia, comprising a complex interplay of social, cultural and environmental dimensions.

16 For contextual approaches to socio-legal research, see R. Cotterrell, 'Subverting Orthodoxy, Making Law Central: A View of Sociolegal Studies' (2002) 29(4) Journal of Law and Society, pp. 632-44.

17 For a recent example see C.J. Bauer, 'Water Conflicts and Entrenched Governance Problems in Chile's Market Model' (2015) 8(2) Water Alternatives, pp. 147-72.

18 But see Macpherson, n. 15 above. 
revealing new insights and common lessons around the protection of Indigenous water rights (or lack of) in these regions.

Most significantly, from both a methodological and ontological perspective, the authors in this collection include a river itself. The Martuwarra RiverOfLife is lead author of the final article 'Recognizing the Martuwarra's First Law Right to Life as a Living Ancestral Being', along with Anne Poelina, Donna Bagnall and Michelle Lim. ${ }^{19}$ It is, to my knowledge, the first time that a river has been the author of an article in a law journal, and is a fitting embodiment of the Symposium themes.

The themes that emerge from this Symposium collection are myriad, but all highlight the variety of tensions involved in delivering both 'jurisdiction' and 'distribution' for Indigenous water rights. ${ }^{20}$ The Symposium can be situated in the context of two unresolved questions in comparative debates about Indigenous water rights:

- How does, or can, law respond to Indigenous demands for recognition of Indigenous interests in water via their direct participation in or control of water governance?

- How does, or can, law respond to Indigenous demands for a fair share of substantive water use rights?

The first question alludes to broader debates around Indigenous-led water governance and alternative worldviews on natural resource management, such as ecosystem rights, 'ecocentrism', legal person/subject models, earth jurisprudence, biocultural rights, and the rights of nature, which are sometimes (but not always) reflective of or driven by Indigenous ontologies. ${ }^{21}$ The second question raises complex challenges around rights allocation and competition between users (including broader water users, Indigenous peoples, and the environment), going to the heart of western assumptions about 'property rights'. It engages with the impact of development, resource exclusion and enclosure on Indigenous peoples, as well as Indigenous rights to self-determination and development in international and comparative law. ${ }^{22}$

19 N. 40 below.

20 This model was developed in Macpherson, n. 15 above.

21 For further consideration of legal person models in comparative contexts see E. O'Donnell, Legal Rights for Rivers: Competition, Collaboration and Water Governance (Routledge, 2018); C. Clark et al., 'Can You Hear the Rivers Sing? Legal Personhood, Ontology, and the Nitty-Gritty of Governance' (2019) 45(5) Ecology Law Quarterly, pp. 787-844; C. Iorns Magallanes, 'Nature as an Ancestor: Two Examples of Legal Personality for Nature in New Zealand' (2015) 22 VertigO: La revue électronique en sciences de l'environnement, pp. 1-17; K. Sanders, “'Beyond Human Ownership?” Property, Power and Legal Personality for Nature in Aotearoa New Zealand' (2018) 30(2) Journal of Environmental Law, pp. 207-34; E. O’Donnell \& J. Talbot-Jones, 'Creating Legal Rights for Rivers: Lessons from Australia, New Zealand, and India' (2018) 23(1) Ecology and Society, pp. 1-10.

22 For further discussion of property rights, enclosure and indigenous peoples, see T. Perreault, 'Dispossession by Accumulation? Mining, Water and the Nature of Enclosure on the Bolivian Altiplano' (2013) 45(5) Antipode, pp. 1050-69; J. Altman, 'Indigenous Interests and Water Property Rights' (2004) 23(3) Dialogue, pp. 29-34; L. Barrera-Hernandez, 'Got Title Will Sell: Indigenous Rights to Land in Chile and Argentina', in A. McHarg et al. (eds), Property and the Law in Energy and Natural Resources (Oxford University Press, 2010), pp. 185-209; M. Trebilcock \& P.E. Veel, 'Property Rights and Development: The Contingent Case for Formalization' (2008) 30(2) University of Pennsylvania Journal of International Law, pp. 397-481; L. Godden, O. Mazel \& M. Tehan, 
As an exercise in comparative law, this Symposium aims to offer theoretical and empirical insights into transnational legal developments, with the purpose of enabling readers to experience new reflections on their own systems and problems. ${ }^{23}$ The Australasian and Latin American comparator countries discussed in the Symposium articles are different in many respects, although they share similar experiences in matters of Indigenous water jurisdiction and distribution. For this reason, the articles play close attention to the social, cultural, political, and historical context to the law in order to avoid misinterpreting other 'legal languages'. ${ }^{24}$ The authors have been encouraged to be 'critically reflective' about their own cultural differences, assumptions and perspectives, ${ }^{25}$ and their contributions should be read with this in mind.

The Symposium collection opens with two positioning articles, which introduce key theoretical challenges in the legal treatment of Indigenous water rights, environmental law and the rights of nature, and highlight opportunities and threats they pose to Indigenous leadership, jurisdictions, and claims.

In their article 'Stop Burying the Lede: The Essential Role of Indigenous Law(s) in Creating Rights of Nature', Erin O'Donnell, Anne Poelina, Alessandro Pelizzon and Cristy Clark explore the intersection of the rights of nature and the rights of Indigenous peoples in legal theory and doctrine. ${ }^{26}$ The authors point to a gradual 'mainstreaming' of the 'rights of nature' movement in comparative environmental law since the Ecuadorian Constitution of 2008. However, they argue that dominant articulations of the rights of nature typically 'bury the lede', and often fail to recognize that the most transformative cases of rights of nature have been influenced and led by Indigenous peoples. If left unchecked, they argue, the rights of nature movement risks 'environmental colonialism', in which the injustices of historical colonization are repeated as Indigenous leadership and lawmaking power (jurisdiction) is not respected and Indigenous ontologies are merely assimilated into western legal frameworks as 'weak legal pluralism'. ${ }^{27}$ The authors argue, instead, for a new ecological jurisprudence that is 'inherently intercultural', 'pluralist', and 'truly transformative'. ${ }^{28}$ This requires recognizing Indigenous leadership through a co-design and co-management approach, and genuine interaction with Indigenous cultures, languages, and ontologies. ${ }^{29}$

'Accommodating Interests in Resource Extraction: Indigenous Peoples, Local Communities and the Role of Law in Economic and Social Sustainability' (2008) 26(1) Journal of Energy \& Natural Resources Law, pp. 1-30.

23 E. Örücü, 'Methodology of Comparative Law', in J.M. Smits (ed.), Encyclopedia of Comparative Law (Edward Elgar, 2006), pp. 442-54, at 442, 445.

24 M. de S.-O.-L'E. Lasser, 'The Question of Understanding', in P. Legrand \& R. Munday (eds), Comparative Legal Studies: Traditions and Transitions (Cambridge University Press, 2003), pp. 197239, at 212-3.

25 Ibid., p. 198.

26 E. O’Donnell, A. Poelina, A. Pelizzon \& C. Clark, 'Stop Burying the Lede: The Essential Role of Indigenous Law(s) in Creating Rights of Nature' (2020) 9(3) Transnational Environmental Law, pp. 403-27.

27 Ibid., pp. $412,426$.

28 Ibid., pp. $412,427$.

29 Ibid., p. 427. 
The authors test their hypothesis by examining comparatively the influence of Indigenous peoples in five cases where lakes and rivers have been recognized as legal persons (in the US, Bangladesh, India, Colombia, and Aotearoa New Zealand), assessing each against their normative standard for intercultural ecological jurisprudence. They contrast these findings with their discussion of the Indigenous-led case of the Mardoowarra/Martuwarra/Fitzroy River in Australia. This opening piece marks an important way forward to guide the other articles in the Symposium collection. It emphasizes the imperatives of Indigenous justice on the basis of their right to selfdetermination, and respect for their law, towards an ecological jurisprudence that is truly de-colonized.

In his article 'Rights of Nature, Legal Personality, and Indigenous Philosophies', Mihnea Tănăsescu explores the relationship between these concepts by comparing cases from Ecuador and Aotearoa New Zealand. ${ }^{30}$ As Tănăsescu acknowledges, much scholarship on the rights of nature works on the underlying assumption that the movement mobilizes a form of ecocentrism founded in Indigenous philosophies. Consistent with the opening contribution to this Symposium, Tănăsescu interrogates critically the concepts of legal personhood and nature's rights in relation to rivers, forests and ecosystems, engaging deeply with their theoretical, epistemological, and empirical foundation and with the related concepts of 'ecocentrism' and 'guardianship'. As case studies, he explores the first major elaboration of the rights of nature in Ecuadorian constitutional law and contrasts it with the recognition of New Zealand's Urewera Forest as a legal person. Both achievements are commonly presented as being reflective of Indigenous ontologies like sumak kawsay or buen vivir in Ecuador ('living well' in Quechua and Spanish, respectively) and kaitiakitanga in Aotearoa New Zealand ('guardianship' in Māori). He warns that the idea of the rights of nature, as an ongoing 'experiment' in Indigenous political authority, fails to realize the full potential of Indigenous ontologies by 'sidestepping' notions of relationality and reciprocity with respect to nature. ${ }^{31}$ It may in fact serve as a 'straitjacket' for Indigenous claims and aspirations. ${ }^{32}$ An important comparative finding is that there are risks involved in identifying too closely Indigenous philosophies with the rights of nature, as this may diminish the radical potential of alternative political arrangements. ${ }^{33}$

The Symposium collection continues with a series of studies of Indigenous water rights in comparative domestic laws. In line with Legrand's method of 'comparing in circles', 34 this part begins with Aotearoa New Zealand, the home jurisdiction for the research workshop which was the catalyst for the Symposium, and a relative epicentre for legal innovations around Indigenous and ecosystem rights.

30 M. Tănăsescu, 'Rights of Nature, Legal Personality, and Indigenous Philosophies' (2020) 9(3) Transnational Environmental Law, pp. 429-53.

31 Ibid., p. 452.

32 Ibid., p. 429.

33 Ibid., p. 453.

34 P. Legrand, 'Comparing in Circles', in P. Nicholson \& S. Biddulph (eds), Examining Practice, Interrogating Theory: Comparative Legal Studies in Asia (Martinus Nijhoff, 2008), pp. 1-8. 
In their article 'River Co-governance and Co-management in Aotearoa New Zealand: Enabling Indigenous Ways of Knowing and Being', Karen Fisher and Meg Parsons discuss the Treaty of Waitangi settlement between the Crown and Ngāti Maniapoto iwi [tribe] with respect to the Waipā River. ${ }^{35}$ They explain how Ngāti Maniapoto recognize the river as an indivisible material and metaphysical entity and taonga [treasure], which is inherently connected to the iwi, and includes the entire riverine environment comprising its 'water, banks, bed, streams, waterways, tributaries, lakes, fisheries, vegetation, floodplains, wetlands, islands, springs, geothermal springs, water column, airspace, and substratum' ${ }^{36}$ They detail the historical and contemporary context to the legislation and policy arrangements enabling the Waipā River settlement, including enhancements of Māori involvement in governance under resource management legislation. Their in-depth empirical research into Māori-Crown engagement about, and co-management of, the river allows them to make significant new findings about the ways in which governments might recognize Indigenous relationships and responsibilities, mātauranga [Indigenous knowledge] and tikanga [law and custom] with regard to rivers. This provides new opportunities to improve the health of aquatic environments. The authors combine legal and policy analysis with historical archival data and biocultural knowledge of the rights and customs of the Maniapoto peoples to triangulate their findings on Waipā River rights and management. Using this interdisciplinary approach, they show how negotiated settlements can provide opportunities to address Indigenous water injustice, by establishing governance frameworks that embrace legal and ontological pluralism. Like previous authors, they highlight the potential for co-governance and co-management arrangements to transform river management, enabling Indigenous water jurisdictions and supporting 'sustainable and just river futures for all'. ${ }^{37}$

The Symposium then travels across the Pacific to two places in Latin America where Indigenous water rights, and broader issues of environmental water management, are acutely challenging. In 'Towards a Holistic Environmental Flow Regime in Chile: Providing for Ecosystem Health and Indigenous Rights', Elizabeth Macpherson and Pia Weber Salazar critically examine the treatment of environmental river flows in Chilean legal and policy frameworks, and the extent to which these frameworks accommodate Indigenous water rights and interests. ${ }^{38}$ The authors provide a detailed account of the historical, legal, and political management of environmental flows in Chile, drawing on a rich archive of Spanish-language legal and policy documents. They highlight a lack of effective protection for water health and Indigenous rights in Chile until at least the end of the $20^{\text {th }}$ century, which has had serious negative environmental and social consequences, despite strong legal protections existing in Chilean constitutional

35 K. Fisher \& M. Parsons, 'River Co-governance and Co-management in Aotearoa New Zealand: Enabling Indigenous Ways of Knowing and Being' (2020) 9(3) Transnational Environmental Law, pp. 455-80.

36 Ibid., p. 460.

37 Ibid., p. 480.

38 E.J. Macpherson \& P. Weber Salazar, 'Towards a Holistic Environmental Flow Regime in Chile: Providing for Ecosystem Health and Indigenous Rights' (2020) 9(3) Transnational Environmental Law, pp. 481-519. 
law. They argue that there is an urgent need for a comprehensive minimum flow regime in Chile to protect the environmental qualities of rivers, which must also reflect and provide for Indigenous water rights, interests, and custodianship. They maintain that Chile's relatively strong constitutional and international norms support such a reform agenda, and they suggest that the developing constitutional crisis in Chile highlights an urgent need to revisit sensitive and unresolved issues of water governance and equity. This contribution highlights the need for overarching normative objectives in constitutional and international law to be backed up by policy and practice realities, and draws attention to the challenges that competing water users pose for those seeking distributive justice for Indigenous water claims.

In the article 'Constitutional Law, Ecosystems, and Indigenous Peoples in Colombia: Biocultural Rights and Legal Subjects', Elizabeth Macpherson, Julia Torres Ventura and Felipe Clavijo Ospina consider the proliferating Colombian jurisprudence on ecosystem rights. ${ }^{39}$ As the authors show, Colombia is increasingly credited as a hotbed for the rights of nature movement and for legal person/subject models. The authors carry out a detailed study of recent court decisions in which rivers and related ecosystems have been recognized as legal subjects in Colombian constitutional law (including the cases concerning the Atrato River and the Colombian Amazon), querying the involvement of and engagement with Indigenous peoples in each instance. As a comparative exercise, the authors ask whether legal rights for rivers and ecosystems could help Indigenous peoples and local communities elsewhere to demand better and more collaborative river and ecosystem management within traditional areas. Consistent with theoretical propositions made in earlier contributions to this Symposium, they find that in some cases where rivers and related ecosystems are recognized as legal subjects the courts have ignored or obscured the rights and perspectives of Colombia's Indigenous peoples, even though they and their tenures are directly affected. The Constitutional Court's decision recognizing the Atrato River as a legal subject under the guardianship of Indigenous and Afrodescendent peoples was a promising attempt to recognize local water jurisdiction via the concept of 'biocultural rights'; yet subsequent cases, like the Colombian Amazon decision, appear to overlook and exclude Indigenous peoples despite their effect on vast Indigenous landholdings. The authors use the Colombian river cases as a caution to courts and legislatures in comparative contexts to be mindful of the rights and interests of local communities and the social, cultural, and environmental complexities of land tenure. They argue that only with strong community buy-in do legal rights for rivers and ecosystems offer the potential for increased Indigenous involvement in and control over natural resource management and, consequently, improved Indigenous-governmental relationships.

The Symposium comes full circle back across the Pacific to Australia, with a call for Indigenous-led water justice in 'Recognizing the Martuwarra's First Law Right to Life as a Living Ancestral Being', by the Martuwarra RiverOfLife, Anne Poelina, Donna

39 E. Macpherson, J. Torres Ventura \& F. Clavijo Ospina, 'Constitutional Law, Ecosystems, and Indigenous Peoples in Colombia: Biocultural Rights and Legal Subjects' (2020) 9(3) Transnational Environmental Law, pp. 521-40. 
Bagnall and Michelle Lim. ${ }^{40}$ The lead author of the article is the Martuwarra (Fitzroy River) in the remote Kimberley region in the far north-western corner of Australia, a living ancestral being from source to sea under the First Law of the Martuwarra Nations. The article begins with a 'Welcome to Country' in which the Martuwarra River introduces itself, acknowledges its sacred connections and relationships, and invites readers to come on a journey through River Country. The authors explore the historical and cultural construction of River Country and Peoples in First Law, providing a rare glimpse into the relationality between peoples and water resources in Indigenous law and custom, as well as the recognition (or non-recognition) of this relationality in western law.

The article is deeply interdisciplinary, triangulating western legal and scientific research with Indigenous ontologies and epistemologies, as part of an effort to de-centre the privilege of human authors. The authors introduce the 2016 Fitzroy River Declaration by the Martuwarra Fitzroy River Council, ${ }^{41}$ which acknowledges the guardianship of Traditional Owners of the Martuwarra catchment and their concern over the impacts of development on the river. They discuss the ongoing frustrations of Traditional Owners with the failure of Australian native title laws to recognize the full extent of Indigenous law, custom, and custodianship. They draw lessons from the settlement of Māori Treaty of Waitangi claims to the Whanganui River in Aotearoa New Zealand to argue for full recognition of Traditional Owner rights to and governance of the Martuwarra River as an integrated living entity. The River concludes by urging legal scholars, courts, law and policy makers, as well as the citizens of our world, to embrace the Martuwarra as an integrated living ancestral being. The Martuwarra case serves as a potential incipient model for rights of nature, legal person/subject, or ecosystem rights arrangements to be elaborated in a way that respects Indigenous rights, belief systems, and leadership.

There are important lessons to be drawn from the findings across this Symposium, including new insights about the dual imperatives of jurisdiction and distribution in delivering Indigenous water justice. Although each article in this Symposium must be considered in its particular historical, political, and cultural context, all pieces highlight Indigenous cultural differences and the need for environmental and water laws to be genuinely intercultural. The articles frame water variously as 'living entities', 'relatives', 'ancestors' and 'more than human', supported by the intergenerational obligations of Indigenous peoples to care for treasured water resources as guardians.

Underlying themes throughout the Symposium are the struggle of Indigenous peoples and ontologies against the 'dominance' of western legal frameworks concerning water and the environment and the need for transformative change. This requires law to be genuinely plural, by decentring and acknowledging the privilege of settler-colonial state law, in order to give jurisdiction to Indigenous cultures, languages,

40 Martuwarra RiverOfLife, A. Poelina, D. Bagnall \& M. Lim, 'Recognizing the Martuwarra's First Law Right to Life as a Living Ancestral Being' (2020) 9(3) Transnational Environmental Law, pp. 541-68.

41 N. 7 above. 
and ontologies. It also demands engagement with ongoing distributive injustices around water rights recognition and allocation in the face of increasing water competition and conflict, and the enclosure of Indigenous territories by other land, water and resource users. The 'experiments' of rights of nature, ecosystem rights and legal personhood may afford new opportunities for Indigenous leadership and authority in water governance, but this must not be at the expense of more radical Indigenous agendas, including distributive claims. Overarching normative objectives for Indigenous rights and the rights of nature in constitutional and international law must be backed up by policy and practice realities and involve, at a minimum, a genuine co-design and co-management approach which does not obscure Indigenous perspectives, rights, and tenures. It gives me great pleasure to introduce this Symposium collection on Indigenous Water Rights in Comparative Law - a significant, original contribution to ongoing transnational debates about Indigenous water justice. 